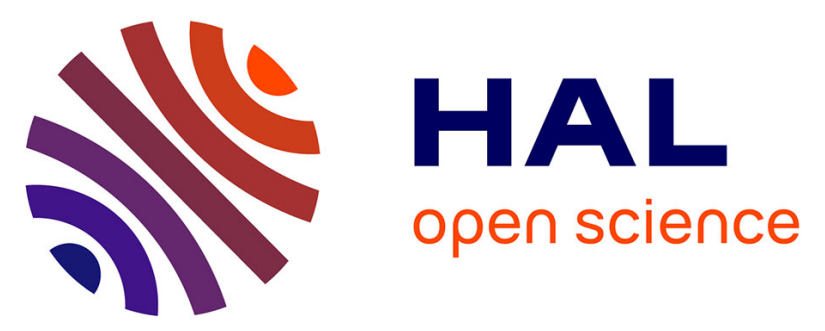

\title{
Development and characterization of viticulture by-products for building applications
}

Céline Badouard, Fabien Bogard, Christophe Bliard, Mohammed Lachi, Boussad Abbes, Guillaume Polidori

\section{To cite this version:}

Céline Badouard, Fabien Bogard, Christophe Bliard, Mohammed Lachi, Boussad Abbes, et al.. Development and characterization of viticulture by-products for building applications. Construction and Building Materials, 2021, 302, pp.124142. 10.1016/j.conbuildmat.2021.124142 . hal-03376896

\section{HAL Id: hal-03376896 https://hal.science/hal-03376896}

Submitted on 21 Oct 2021

HAL is a multi-disciplinary open access archive for the deposit and dissemination of scientific research documents, whether they are published or not. The documents may come from teaching and research institutions in France or abroad, or from public or private research centers.
L'archive ouverte pluridisciplinaire $\mathbf{H A L}$, est destinée au dépôt et à la diffusion de documents scientifiques de niveau recherche, publiés ou non, émanant des établissements d'enseignement et de recherche français ou étrangers, des laboratoires publics ou privés.

\section{(1) (1) $\$$}

Distributed under a Creative Commons Attribution - NonCommercial - NoDerivatives| 4.0 


\title{
Development and characterization of viticulture by-products for building applications
}

\author{
Céline Badouard ${ }^{\mathrm{a}, \mathrm{b}, \mathrm{c}}$, Fabien Bogard ${ }^{\mathrm{a}, \mathrm{b}}$, Christophe Bliard ${ }^{\mathrm{c}}$, Mohammed Lachi $^{\mathrm{a}}$, Boussad Abbes ${ }^{\mathrm{a}}$, Guillaume Polidori ${ }^{\mathrm{a}, \mathrm{b}}$ \\ ${ }^{a}$ MATIM, Université de Reims Champagne Ardenne, Moulin de la Housse, BP 1039, 51687 Reims Cedex 2, France \\ ${ }^{\mathrm{b}}$ Pôle de Recherche Châlonnais, Campus URCA Châlons, Université de Reims Champagne Ardenne, Chaussée du Port, 51000 Châlons \\ en Champagne, France \\ c Institut de Chimie Moléculaire de Reims, ICMR-UMR 7312 CNRS, Université de Reims Champagne Ardenne, Moulin de la Housse, \\ BP 1039, 51687 Cedex 2, France
}

*Corresponding authors: fabien.bogard@univ-reims.fr

Keywords: Potato starch, Building insulation, Bio-sourced composite, Mechanical properties, Sound absorption, Porosity

\begin{abstract}
This work deals with the manufacture of new bio-based materials for building insulation from viticulture by-products, and potato starch. Four types of aggregates were used separately: grape pomace, stalks, skins, and crushed stalks. The starch/aggregate mass ratio was set at $20 \%$ starch. The samples obtained were characterized in terms of density, thermal conductivity, compressive and bending strength, and sound absorption coefficient. The thermal conductivity of the different composites was found to be ca $0.075 \mathrm{~W} /(\mathrm{mK})$. Compression tests showed a high compression resistance from the starch/stalk, grape pomace/starch, and crushed stalk/starch composites. The high sound absorption coefficient indicated that these materials can be used as sound absorbers, especially the starch/grape pomace composite with a measured absorption coefficient of 0.42 for a low thickness of $20 \mathrm{~mm}$ only. Overall, grape by-products/starch composites seem to have good thermal, mechanical, and acoustic performance for use as insulation materials in public building construction.
\end{abstract}

\section{Introduction}

The building sector is one of the largest consumers of natural resources and energy in the world. During their lifetime (construction, operation, maintenance, and demolition), buildings consume a considerable amount of primary and natural resources (30 to 40\%) and account for $30 \%$ of global greenhouse gas emissions, as well as air, water, and land pollution [1]. EU Directive 2018/844 requires a minimum energy performance for new buildings as well as for existing buildings. Europe encourages its members to renovate buildings in order to decrease energy consumption in this sector [2]. Insulation is one of the key parameters for the energy performance of buildings. The increase in the world's population is causing a high demand for building materials inducing a programmed scarcity in the medium term for fossil or mineral based materials. [3]. One of the options, for non-load bearing materials, is the use of bio-based materials whose resources are renewable. Agro-wastes have a growing interest for valorization as biosourced materials for insulation. Among them, flax [4], hemp [5], maize [6], sunflower [7], rapeseed straw [8] are alternatives to mineral insulation with significant quantities available in France. Other studies have been reported using unconventional materials such as cotton stalks [9], banana bunch [10], rice straw [11], palm leaves [12], pineapple leaves [13], reeds [14], bagasse sugar cane [15], ... Each of these natural alternatives to the use of petroleum derivatives is interesting for the building sector because they have remarkable properties from the acoustic, thermal or mechanical point of view.

Waste and by-products from the market gardening sector was also studied to produce composites [16]. Grapes are widely grown in the world for both fruit, grape juice and wine. Wine production generates a considerable amount of grape pomace, in France, 850000 tons per year [17]. The grape pomace also called "aignes", in Champagne region, correspond to all the solid parts that remain at the end of the pressing process. Traditional methods for the treatment of grape pomace include distillation, composting, combustion, gasification, and pyrolysis [18, 19]. However, these by-products have potential for higher added value materials [20]. Grape pomace has compounds of interest such as tartar [21], citric acid [22], malic acid, dietary fiber [23], lipids [24] and phenolic compounds [25]. Current applications of these by-products are in the food, cosmetics and pharmaceutical industries for antioxidant, preservative and texturizing properties [26], but also the development of resin based on condensed tannins for particle boards [27], powdered grape pomace filled polymers [28, 29] and starch/starch foams for the packaging sector [30].

Starch is a polysaccharide present in a large variety of agricultural crops such as cereals, tubers, and legumes. Starch is composed of two structurally different polymers: amylose (linear) and amylopectin (branched). Starch is used in many 
industrial sectors such as papermaking, food processing, pharmaceuticals, and plastics industry. Starch is also used for the elaboration of biosourced composites for applications in civil engineering such as hemp/starch composites, date palm fiber/cassava starch, sugarcane fiber/cassava starch and beet pulp/potato starch. [31, 32, 33].

The aim of this study is to find a way of valorization for the by-products of viticulture. In spite of efforts made on wine byproducts valorization, a large quantity of grape pomace is still not currently valorized. One of the motivations of the present work was to design a $100 \%$ biosourced material derived from the resources found in the Champagne-Ardennes region to encourage the development of local production sectors. This region of France has the particularity of producing agricultural product as well as a famous wine (Champagne). The current development of bio-sourced materials responds to a logic of searching for a unique material with multifunctional properties, efficient from a mechanical, thermal, and acoustic point of view, rather than a juxtaposition of materials responding to one of these three functions. Different types of agro-composites were elaborated with starch/grape pomace, starch/skins, starch/stalks and starch/crushed stalks, giving an eco-material of natural origin, recyclable, renewable and storing carbon over decades. The physical-mechanical, thermal, and acoustic characteristics were measured on the composites elaborated for a use in the building sector for nonload bearing and insulation applications. These agrocomposites would offer an alternative solution to the currently used mineral or fossil-based materials (glass wool, rock wool, polyurethane foam, polystyrene, ...).

\section{Materials and Methods \\ 2.1. Potato starch}

The potato starch was purchased from Roquette, Lestrem, France. Potato starch has a high degree of polymerization, which gives a highly viscous binder and provides good mechanical properties, ideal for the manufacture of composites.

In the presence of water heated over $80^{\circ} \mathrm{C}$, the starch grains swell under an irreversible gelatinization process [34]. The resulting dried starch gel serves as a binder that stabilizes the resulting composite structure, transmitting shear forces within the aggregates.

\subsection{Grape pomace characterization}

\subsubsection{Description}

Grape pomace is constituted of the grape skins, stalk, and seeds (Fig. 1) which are mostly composed of cellulose, hemicellulose, pectin, sugars, proteins, lipids, and polyphenols [35]. The stalks are high in cellulose, hemicelluloses, lignin, tannins, and ash, for the most part [36]. Grape skins are mostly composed of cellulose, proteins, tannins, terpenes, fatty acids and minerals, with some remaining sugars in varying proportion according to the grape types and maturity [37]. The composition of the grape pomace depends on its origin (distillery, winegrower, ...). The grape pomace were used crude, destemmed, deseeded or crushed.

For this work, the whole grape pomace was recovered after the September 2020 grape harvest. The grape pomace used were from the pinot noir variety. Before use, the grape pomace was washed to remove residual sugar. In this study, four batches of aggregates were studied: one batch using the entire grape pomace (GP), two other batches using stalks (S) and skins $(\mathrm{P})$ separately and a final batch of coarsely $(<5 \mathrm{~mm})$ grounded stalks (CS). All samples were dried for 72 hours at $50^{\circ} \mathrm{C}$ in a tray dryer.

In order to determine the proportion of the different components that make up the grape pomace, i.e. skins, stalks and seeds, a batch of $5 \mathrm{~kg}$ was carefully treated to separate the different elements. They were weighed before and after washing and drying to measure the water and residual sugar content (80\%). The obtained mass distribution was, 12.7 wt $\%$ stalks, $51.3 \mathrm{wt} \%$ skins \& pulp and $36 \mathrm{wt} \%$ seeds.

The stalk is composed of a peduncle that is attached to the vine shoot and small branches that support each berries. The peduncles can be between 30-200 mm long and have numerous branches. The grape skins are about $10 \mathrm{~mm}$ in diameter and less than $1 \mathrm{~mm}$ thick (Fig. 1). The stalks were ground to separate the branches and reduce the size to less than $5 \mathrm{~mm}$. A description of the shape of the aggregates allows a better understanding of the elaboration and characterization of these composites. 


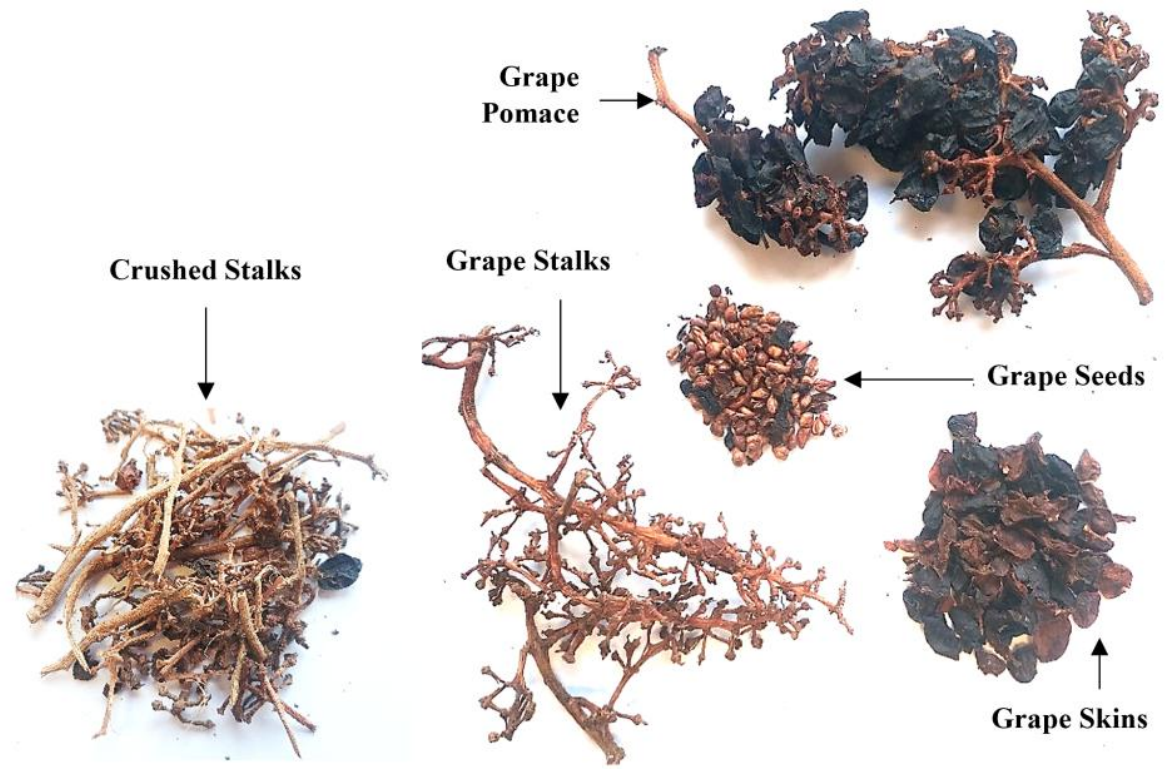

Figure 1: The different elements composing the grape pomace (the stalk, the seed, and the skins) and crushed stalks

\subsubsection{Density}

Knowledge of component density is important to analyze and understand the properties of composites. The density is defined as the mass of the unit volume of a material, obtained with Eq.1. Porosity is an essential characteristic for evaluating insulation properties. Natural fibers such as grape pomace components have different levels of porosities due to their complex structures. The bulk density is the ratio between the mass of the particles and the bulk volume which includes the volume of the solid, the volume of the pores and the volume of the space between the solid parts. The solid parts apparent density is the ratio between the mass of material and the apparent volume of the individual solid items, from which the interstitial air between the parts is subtracted. The absolute density is the ratio of the mass of the material to the real volume from which the volume of the pores (open and closed) within the solid fiber parts has been subtracted. Measurements of each density were made five times on each solid (grape pomace, stalks, skins and starch). The bulk density measurements were made using a $100 \mathrm{~mL}$ volumetric flask. The flask was filled with aggregates without compaction to get the desired volume. The density was calculated using Eq.1.

$$
\rho_{\text {bulk }}=\frac{m}{V}
$$

where $\rho_{\text {bulk }}$ is the density of the aggregates in $\mathrm{kg} / \mathrm{m}^{3}, \mathrm{~m}$ the mass of the aggregates in $\mathrm{kg}, \mathrm{V}$ the volume occupied by the aggregates in $\mathrm{m}^{3}$.

The fibers apparent density was measured by replacing interstitial air with sand less than $250 \mu \mathrm{m}$ in size. The volumetric flask is then filled with a known volume of sand. The system was compacted manually or with a vortex vibrator until the maximum compaction given volume was reached. The real density is given by Eq.2:

$$
\rho_{\text {fibers app. }}=\frac{m_{a}}{V_{T}-\left(m_{T}-m_{a}\right) / \rho_{\text {sand }}}
$$

where $\rho_{\text {fibers app. }}$ is the fibers apparent density of aggregates in $\mathrm{kg} / \mathrm{m}^{3}, \mathrm{~m}_{\mathrm{a}}$ the mass of aggregates in $\mathrm{kg}, \mathrm{m}_{\mathrm{T}}$ the total mass (sand + aggregates) in $\mathrm{kg}, \mathrm{V}_{\mathrm{T}}$ the total volume of the system in $\mathrm{m}^{3}, \rho_{\text {sand }}$ the density of sand in $\mathrm{kg} / \mathrm{m}^{3}$.

The method used for the measurement of absolute density was already described in [31] using the cyclohexane method. In short a pycnometer was filled with a known mass of sample and cyclohexane was added up to half of the pycnometer volume. The system undergoes six cycles of boiling (30 min) and cooling (10 min). During these cycles, air escapes from inside the void of the fibers that are replaced gradually by liquid cyclohexane during cooling. At the end the pycnometer was filled to the top and capped with the stopper, ensuring that no bubbles were trapped inside. The system was weighed with an accuracy of $10^{-3} \mathrm{~g}$. The absolute density was calculated according to Eq.3:

$$
\rho_{\text {abs }}=\frac{M_{1} \times \rho_{\text {cyclohexane }}}{M_{1}-\left(M_{2}-M_{3}\right)}
$$

where $\rho_{\text {abs }}$ is the absolute density in $\mathrm{kg} / \mathrm{m}^{3}, \rho_{\text {cyclohexane }}$ the density of cyclohexane in $\mathrm{kg} / \mathrm{m}^{3}, \mathrm{M}_{1}$ the mass of the dried sample in $\mathrm{kg}, \mathbf{M}_{2}$ the mass of the pycnometer containing cyclohexane in $\mathrm{kg}$ and the dried sample, and $\mathbf{M}_{3}$ the mass of the pycnometer containing cyclohexane only in $\mathrm{kg}$. Each measurement was performed at least five times and the measurements were averaged. The porosity was calculated using Eq. 4: 


$$
\varnothing=1-\frac{\rho_{\text {bulk }}}{\rho_{\text {abs }}}
$$

where $\varnothing$ is the porosity of the composite, $\rho_{\text {bulk }}$ the bulk density in $\mathrm{kg} / \mathrm{m}^{3}$ and $\rho_{\text {abs }}$ the absolute density in $\mathrm{kg} / \mathrm{m}^{3}$.

The theoretical absolute density of the composites was obtained using the rule-of-mixtures modified with Eq.5:

$$
\rho_{c_{a b s}}=\frac{1}{\frac{M_{a}}{\rho_{a} a b s}+\frac{M_{S}}{\rho_{s} a b s}}
$$

where $\rho_{\mathrm{c}}$ abs is the theoretical absolute density in $\mathrm{kg} / \mathrm{m}^{3}, \rho_{\mathrm{a}}$ abs the absolute density of aggregates in $\mathrm{kg} / \mathrm{m}^{3}, \mathrm{M}_{\mathrm{a}}$ the mass rate of the aggregates, $\rho_{\mathrm{s}}$ abs the absolute density of starch in $\mathrm{kg} / \mathrm{m}^{3}$ and $\mathrm{M}_{\mathrm{s}}$ the mass rate of the starch.

\subsection{Composites characterization \\ 2.3.1. Composite elaboration}

In a previous study on the development of a new beet pulp/starch composite, Karaky and al. concluded after analyzing mechanical, thermal, acoustic and water properties that the beet pulp/starch composite with $20 \%$ starch showed the best characteristics. The assumption is made that this value of $20 \%$ will also be the best compromise for the composition and properties of the biosourced material [38].

To facilitate mixing and to ensure homogeneity of the composite, the binder solution was prepared separately. In order to ease the mix of the binder with the solids and to have sufficient stickiness for the adhesion the starch/water ratio was set at 0.1 [39]. For the preparation of the binder, the appropriate quantities of water and starch were heated and mixed until a binder with high viscosity and translucent appearance was obtained. The aggregates used for the formation of the composites were: whole grape pomace (GP), stalks (S), skins (P), crushed stalks (CS) and starch (A). The formulations used were A/GP; A/S; A/P and A/CS with $20 \%$ starch. To ensure both the reproducibility of experiments and the reliability of the results the several samples of various sizes were prepared (Tab.1).

\begin{tabular}{|c|c|c|c|c|c|c|}
\hline \multicolumn{2}{|l|}{ Composites } & Dim. (mm) & A/GP & $\mathbf{A} / \mathbf{S}$ & $\mathbf{A} / \mathbf{P}$ & $\mathrm{A} / \mathrm{CS}$ \\
\hline \multirow{2}{*}{ Mechanical } & Bending & $160 \times 40 \times 40$ & 3 & 3 & 3 & 3 \\
\hline & Compression & $100 \times 100 \times 100$ & 3 & 3 & 3 & 3 \\
\hline \multicolumn{2}{|l|}{ Thermal } & $100 \times 100 \times 100$ & 3 & 3 & 3 & 3 \\
\hline \multirow{2}{*}{ Acoustic } & Large tube & $\emptyset 100,20$ & 3 & 3 & 3 & 3 \\
\hline & Small tube & $\emptyset 29,20$ & 3 & 3 & 3 & 3 \\
\hline
\end{tabular}

Table 1: Number and characteristics of the prepared test samples

The solids were mixed with the binder for $5 \mathrm{~min}$ to achieve homogeneity. The resulting formulations were shaped in molds and compacted with a fitting wooden top to flatten the surface. All specimens were compacted with a stress of ca. 0.05 $\mathrm{MPa}$. The molds were then frozen at $-20^{\circ} \mathrm{C}$ and the frozen samples were dried using a freeze dryer under a pressure of $2-3$ mbar for several days. Different types of molds were used depending on the shape required for the characterization methods. The steps are summarized and illustrated in Fig. 2. 


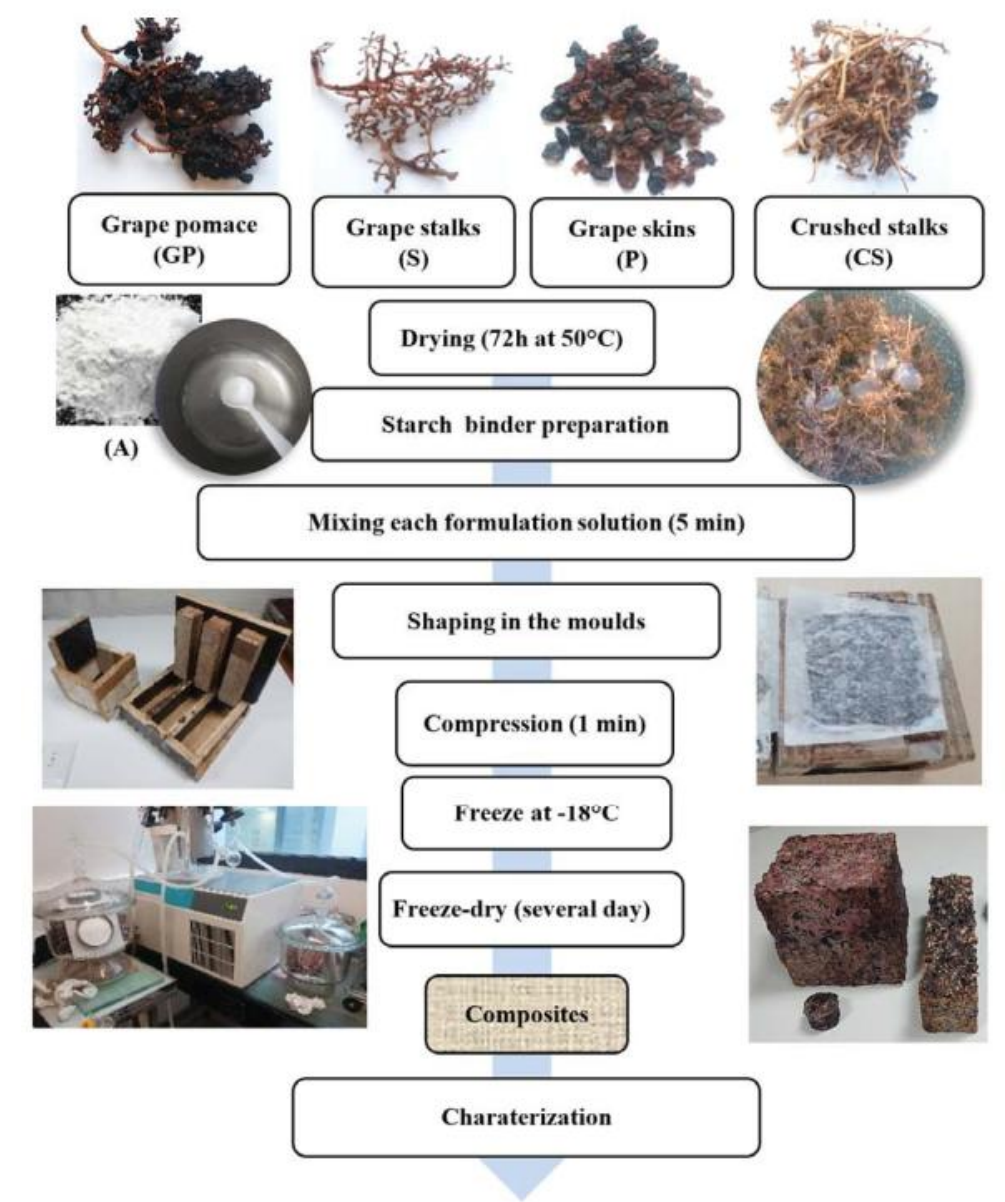

Figure 2: Synthetic diagram of the step of composite manufacturing

\subsubsection{Thermal properties}

The thermal conductivity $(\lambda)$ of the composites was measured using a probe ISOMET 2114 from Applied Precision. The heat flux was generated by heating an electrical resistor inserted into the sample to ensure direct thermal contact with the sample. This measurement analyzes the temperature response of the measured composite to heat flux pulses. The evaluation of thermal conductivity $(\lambda)$ is based on temperature measurements taken periodically as a function of time.

A series of three cubic samples $(100 \times 100 \times 100 \mathrm{~mm})$ for each composition was made (Fig.3). After drying, the samples were equilibrated at $23^{\circ} \mathrm{C}$ and $10 \% \mathrm{RH}$ before measurements. A total of ten measurements were made for each sample and the results were averaged.

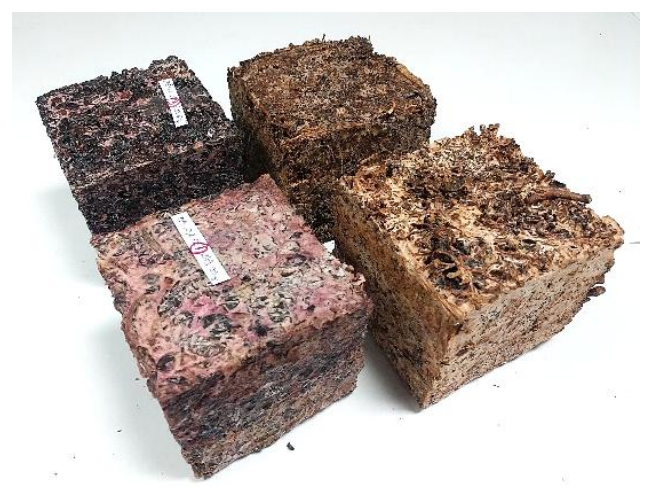

Figure 3: Cubic samples for thermal and compression test

The performance of a thermal insulation is measured in terms of its ability to prevent thermal power from passing through a surface. The thermal resistance is calculated according to Eq. 6. 


$$
R=\frac{e}{\lambda}
$$

where $\mathrm{R}$ is the thermal resistance in $\mathrm{m}^{2} . \mathrm{K} / \mathrm{W}$, e the material thickness in $\mathrm{m}$ and $\lambda$ the thermal conductivity in $\mathrm{W} /(\mathrm{m} . \mathrm{K})$.

\subsubsection{Mechanical properties}

Mechanical tests performed in the same direction of specimen compaction (compression and 3-point bending) were recorded using the Instron 33R 4204 tensile tester apparatus with a $50 \mathrm{kN}$ load cell and a constant displacement speed (10 $\mathrm{mm} / \mathrm{min}$ ) for the bending (Fig. 4b) and compression tests (Fig. 4a).

The compression tests were carried out and averaged on three cubic shaped samples $(100 \times 100 \mathrm{x} 100 \mathrm{~mm})$ for each composition. Hooke's law (Eq. 7) was used to determine stress at rupture in compression:

$$
\sigma_{C}=E \times \varepsilon
$$

where $\sigma_{\mathrm{c}}$ is the stress at rupture in MPa, E the Young's Modulus in MPa and $\varepsilon=\Delta \mathrm{l} / 1, \varepsilon$ the strain at break.

The three-point bending tests were carried out and averaged on three samples of prismatic shape (160 x $40 \mathrm{x} 40 \mathrm{~mm})($ Fig. 4c). Stress at rupture was determined by the Navier equation (Eq.8):

$$
\sigma_{f}=\frac{M f \times y}{I}=\frac{F a}{2 I} y
$$

where $\sigma_{\mathrm{f}}$ is the stress at rupture in $\mathrm{MPa}, \mathrm{M}_{\mathrm{f}}$ the peak bending moment, $\mathrm{F}$ the maximum load in $\mathrm{N}, \mathrm{y}=\mathrm{h} / 2$ is the extreme fiber location, $\mathrm{h}=40 \mathrm{~mm}$ the sample thickness in $\mathrm{mm}, \mathrm{I}=\left(\mathrm{b} \mathrm{x} \mathrm{h}^{3}\right) / 12$, I the quadratic moment of the sample, $\mathrm{b}=40 \mathrm{~mm}$ the width of the sample in $\mathrm{mm}$ and $\mathrm{a}=60 \mathrm{~mm}$ the distance between a support ant the applied load in $\mathrm{mm}$ (Fig. 4d).
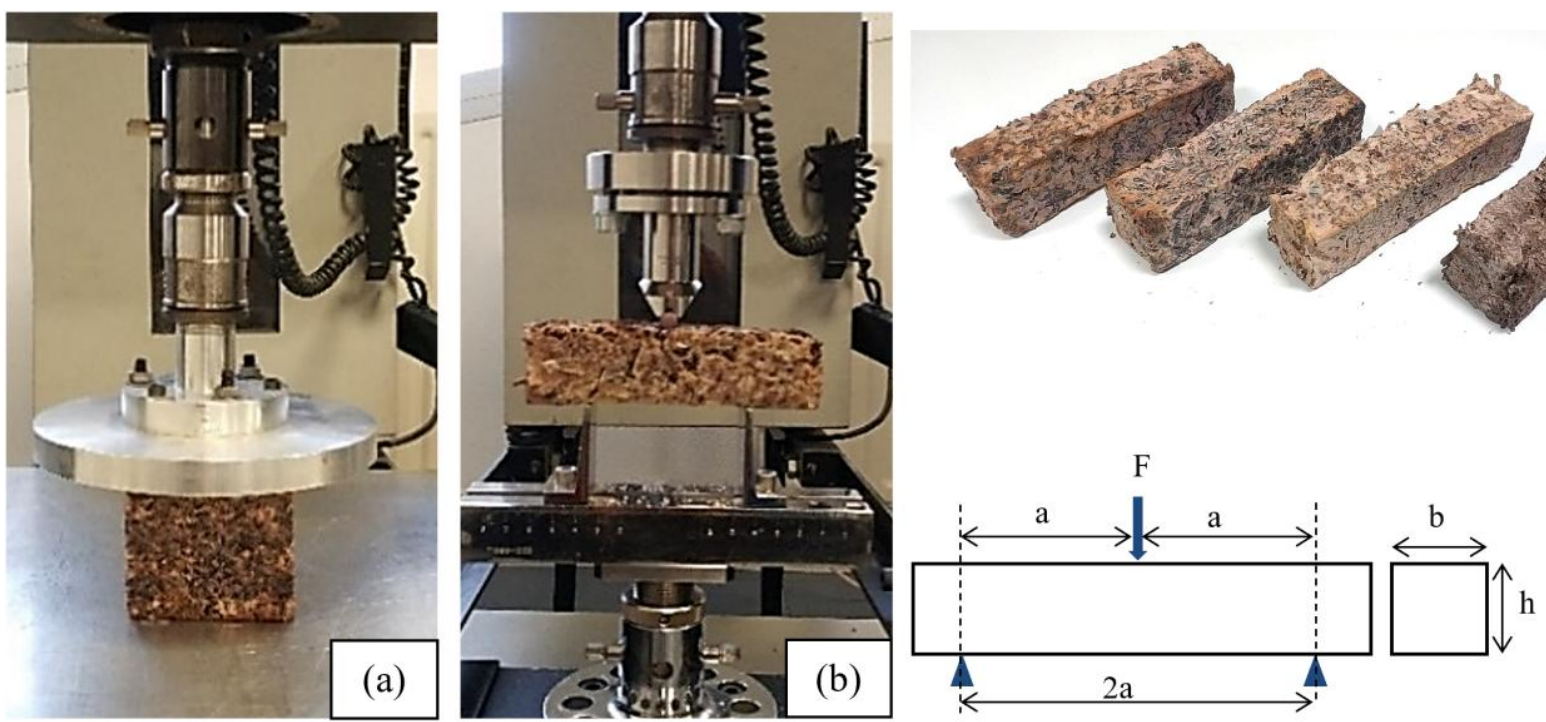

(c)

Figure 4: Compressive test (a), bending test (b) and (d), samples for bending (c).

\subsubsection{Acoustic properties}

The Kundt tube 4206 (tube with two fixed microphones) from Brüel \& Kjaer was used to measure the sound absorption coefficient $\alpha$. This device consists of a cylindrical tube with two quarter-inch microphones type 4187 BK, a power amplifier BK 2735, and a 3160-A-042 analyzer type. The Kundt tube measures sound absorption as well as surface impedance according to NF EN ISO 10534-2.

The sound absorption coefficient is defined as the ratio of the acoustic energy absorbed by a composite to the acoustic energy incident on its surface. The device determines the sound absorption coefficient by measuring the pressure at two fixed points caused by a stationary random sound propagating as a plane wave through the tube.

The sound absorption coefficient was measured in a frequency range between $50 \mathrm{~Hz}$ and $6.4 \mathrm{kHz}$, which corresponds to the frequency range of the noises generally in building. Two tubes of different sizes were used to analyse the entire frequency ranges. The device used for this test is a $100 \mathrm{~mm}$ diameter tube for low frequencies $(50 \mathrm{~Hz}-1.6 \mathrm{kHz})$, (Fig. 5a) and another $29 \mathrm{~mm}$ diameter tube for high frequencies $(500 \mathrm{~Hz}-6.4 \mathrm{kHz})$ (Fig. 5c). 
Cylindrical test pieces (100 mm (Fig. 5b) and $29 \mathrm{~mm}$ (Fig. 5d) diameter) of each formulation were prepared. The edges of the samples were sealed with adhesive tape and an adapter was used to fill in the small gap due to the shrinkage of the samples during to drying procedure and avoid acoustic leakage in the tubes. Measurements were made consecutively on both sides of each sample. The measurements of each batch were averaged over six tests with a measurement resolution of $2 \mathrm{~Hz}$.
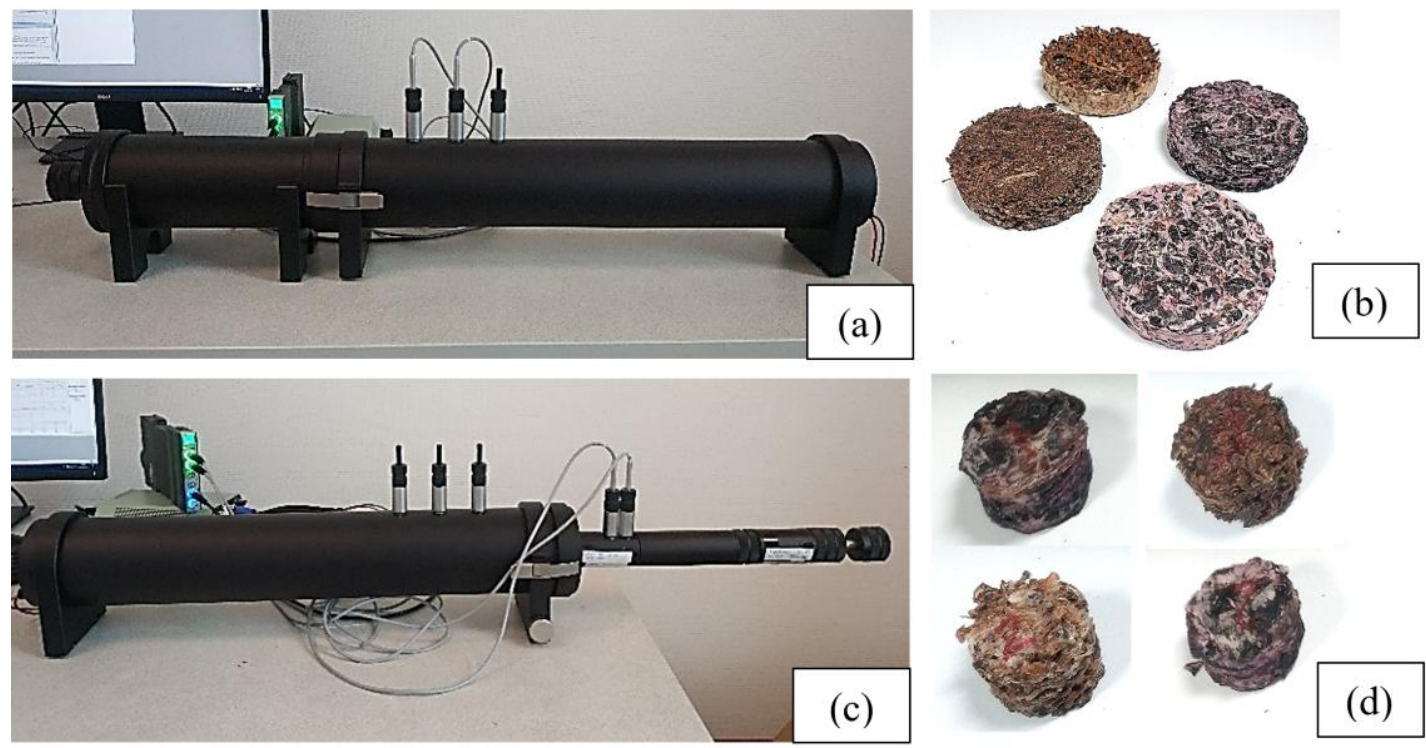

Figure 5: Kundt tube (a) large diameter - low frequency configuration, (b) samples for low frequency measurement, (c) small diameter - high frequency configuration, (d) samples for high frequency measurement

The practical sound absorption coefficient $\left(\alpha_{\mathrm{p}}\right)$ is the average of the three one-third octave values over the center band frequency. The sound absorption coefficient $\left(\alpha_{\mathrm{w}}\right)$ is calculated according to ISO 11654, using the values of the practical sound absorption coefficient $\left(\alpha_{\mathrm{p}}\right)$ based on standard frequencies and compared to a reference curve. The reference curve defined by the standard must be moved in steps of 0.05 to the curve of $\left(\alpha_{p}\right)$ until the values below the reference curve are less than or equal to 0.1 . The $\alpha_{\mathrm{w}}$ parameter corresponds to the value of the reference curve at $500 \mathrm{~Hz}$ (for $20 \mathrm{~mm}$ thick samples in this study).

\section{Results and discussion 3.1. Density and porosity}

The aggregate porosity (Table 2) can be considered as being the global porosity of the different components (stalks, skins,...), the presence of voids between and within the components and the intrinsic porosity which includes the internal voids of the particles. The intrinsic porosity of the particles are: $49 \%$ for the stalks, $51 \%$ for the skins and $45 \%$ for the crushed stalks are close. However, the intrinsic porosities of the pomace $15 \%$ is much lower. This known value can be explained by the fact that the grape was compressed to optimal compaction during grape pressing. The destemming allows the separation of the stalks from the skins.

Table

\begin{tabular}{rcccrrr}
\hline Aggregates & $\begin{array}{c}\boldsymbol{\rho}_{\text {bulk }} \\
\left(\mathrm{kg} / \mathrm{m}^{3}\right)\end{array}$ & $\begin{array}{c}\boldsymbol{\rho}_{\text {fibers app }} \\
\left(\mathrm{kg} / \mathrm{m}^{3}\right)\end{array}$ & $\begin{array}{c}\boldsymbol{\rho}_{\text {abs }} \\
\left(\mathrm{kg} / \mathrm{m}^{3}\right)\end{array}$ & $\begin{array}{c}\text { Porosity } \\
(\%)\end{array}$ & $\begin{array}{r}\text { Int. porosity } \\
(\%)\end{array}$ & $\begin{array}{r}\text { 2: } \\
\text { Dens }\end{array}$ \\
ities \\
Grape Skins (P) & $181 \pm 6$ & $694 \pm 18$ & $1420 \pm 77$ & $87 \pm 1$ & $51 \pm 3$ & $15 \pm 4$ \\
and \\
Grape Pomace (GP) & $109 \pm 8$ & $755 \pm 15$ & $886 \pm 64$ & $88 \pm 1$ & $49 \pm 3$ & the \\
Grape Stalks (S) & $61 \pm 3$ & $524 \pm 19$ & $1022 \pm 71$ & $94 \pm 1$ & poros \\
& & & & & ities \\
& & & & &
\end{tabular}

different aggregates 


\begin{tabular}{rcccccc}
\hline Crushed Stalks (CS) & $116 \pm 5$ & $565 \pm 25$ & $1022 \pm 71$ & $89 \pm 1$ & $45 \pm 4$ & $84 \pm 3$ \\
\cline { 1 - 1 } Freeze-dry starch gel (A) & $178 \pm 7$ & $182 \pm 8$ & $1200 \pm 82$ & $85 \pm 2$ & Pure \\
\hline
\end{tabular}

starch aerogel samples made by freeze-drying a $10 \%$ starch gel in water were prepared in conditions similar to the other compounds then were characterized for density and porosity. The choice of starch as a binder for composites is justified by its shape after drying which gives a foam with a high porosity of $84 \%$. The elements alone have interesting porosities for the desired application since the other insulating materials (glass wool, polyurethane foam, ...) have very porous structures that give them optimal thermal and acoustic properties.

\subsection{Samples composites analysis}

The bulk density of the composites was averaged over twelve samples for each composition. The absolute density of the composites is calculated from Eq.5 using the absolute densities of the raw materials. The porosities are calculated and all the results can be found in Table 3. After freeze drying, a small dimensional variation of all samples was observed. Composites of stalks and crushed stalks present a 5\% shrinkage while skin and grape pomace composites displayed a 10 to $12 \%$ volume shrinkage.

Table 3: Density and porosity of $20 \%$ of starch composites.

\begin{tabular}{rccc}
\hline Composites & $\begin{array}{c}\boldsymbol{\rho}_{\mathbf{c} \text { bulk }} \\
\left(\mathrm{kg} / \mathrm{m}^{3}\right)\end{array}$ & $\begin{array}{c}\boldsymbol{\rho}_{\mathbf{c} \text { abs }} \\
\left(\mathrm{kg} / \mathrm{m}^{3}\right)\end{array}$ & $\begin{array}{c}\text { Porosity } \\
(\%)\end{array}$ \\
\hline $\mathrm{A} / \mathrm{P}$ & $433 \pm 78$ & $1370 \pm 90$ & $68 \pm 5$ \\
$\mathrm{~A} / \mathrm{GP}$ & $308 \pm 32$ & $934 \pm 82$ & $67 \pm 4$ \\
$\mathrm{~A} / \mathrm{S}$ & $227 \pm 47$ & $1053 \pm 85$ & $78 \pm 4$ \\
$\mathrm{~A} / \mathrm{CS}$ & $345 \pm 35$ & $1053 \pm 85$ & $67 \pm 3$ \\
\hline
\end{tabular}

Most of the prepared composites have bulk densities lower than $500 \mathrm{~kg} / \mathrm{m} 3$, they are light structural materials. All composites have the same proportion of starch (20\%); therefore, the density of the composite depend on the density of the aggregates and the compaction. Similarly, the porosity of the composites depends both on the intrinsic porosity of the starch and on the arrangement of the different constituent within the composite (the higher the compaction load, the smaller the voids). The resulting materials therefore have a very porous structure, suitable for the manufacture of insulation material.

\subsection{Thermal characteristics}

Table 4 shows the thermal conductivity measurements $\lambda$ for different aggregate-starch mixtures. The thermal conductivity is almost identical for all composites around (ca $0.0755 \mathrm{~W} /(\mathrm{mK})$ ). The thermal conductivity values obtained for all materials are low, indicating that the materials would have a potential for thermal insulation.

Table 4: Thermal conductivity of the different compositions (with $20 \%$ of starch)

\begin{tabular}{rc}
\hline Composites & $\begin{array}{c}\lambda \\
\mathrm{W} /(\mathrm{mK})\end{array}$ \\
\hline $\mathrm{A} / \mathrm{P}$ & $0,0793 \pm 0,0033$ \\
$\mathrm{~A} / \mathrm{GP}$ & $0,0759 \pm 0,0067$ \\
$\mathrm{~A} / \mathrm{S}$ & $0,0693 \pm 0,0039$ \\
$\mathrm{~A} / \mathrm{CS}$ & $0,0776 \pm 0,0015$ \\
\hline
\end{tabular}

In comparison with other bio-based composites, [40] beet-pulp/starch composite presented conductivity values between 0.069 and $0.076 \mathrm{~W} /(\mathrm{mK})$. The conductivity values for the composites hemp shives, flax shives, sunflower bark, rapeseed straw without added binder range from 0.064 to $0.070 \mathrm{~W} /(\mathrm{mK})$ [41]. Composites based on agroresources seem to have similar thermal conductivities regardless of the nature of the aggregates. The performance of these materials in thermal insulation is due to their low density, which allows for high internal porosity and interstitial voids between the particles. Thermal insulation is mainly based on the very low thermal conductivity of gases. Gases have poor thermal conduction properties compared to liquids and solids and are therefore a good insulating material if they can be trapped (for example in a foam-like structure).

In the field of residential buildings, according to the French standard RT2012, a material is considered as insulating if its thermal conductivity is $<0.065 \mathrm{~W} /(\mathrm{mK})$. However, there is no particular obligation on the insulation performance and materials to be used for buildings with discontinuous occupation (office or commercial) and for renovation [42]. In order for materials to be used for any type of construction, the thermal conductivity must be reduced. Options for reducing 
thermal conductivity include varying the proportion of starch and/or the compression ratio (to vary the density). For various materials, it has been shown that there is an almost linear relationship between thermal conductivity and density [40].

The performance of an insulating material is measured by the ability to reduce heat flow a surface. It is defined by the thermal resistance $(R)$. The French government [43] recommends a thermal resistance $\left(R=2.9 \mathrm{~m}^{2} \mathrm{~K} / \mathrm{W}\right)$ for wall insulation for an entire wall. An entire wall is composed of concrete, insulation, metal studs and plaster. The total thermal resistance of a wall characterizes the sum of the heat transfers achieved by conduction within the materials and the surface heat exchanges achieved by convection and radiation. It is calculated by adding the thermal resistances of the different elements of the wall.
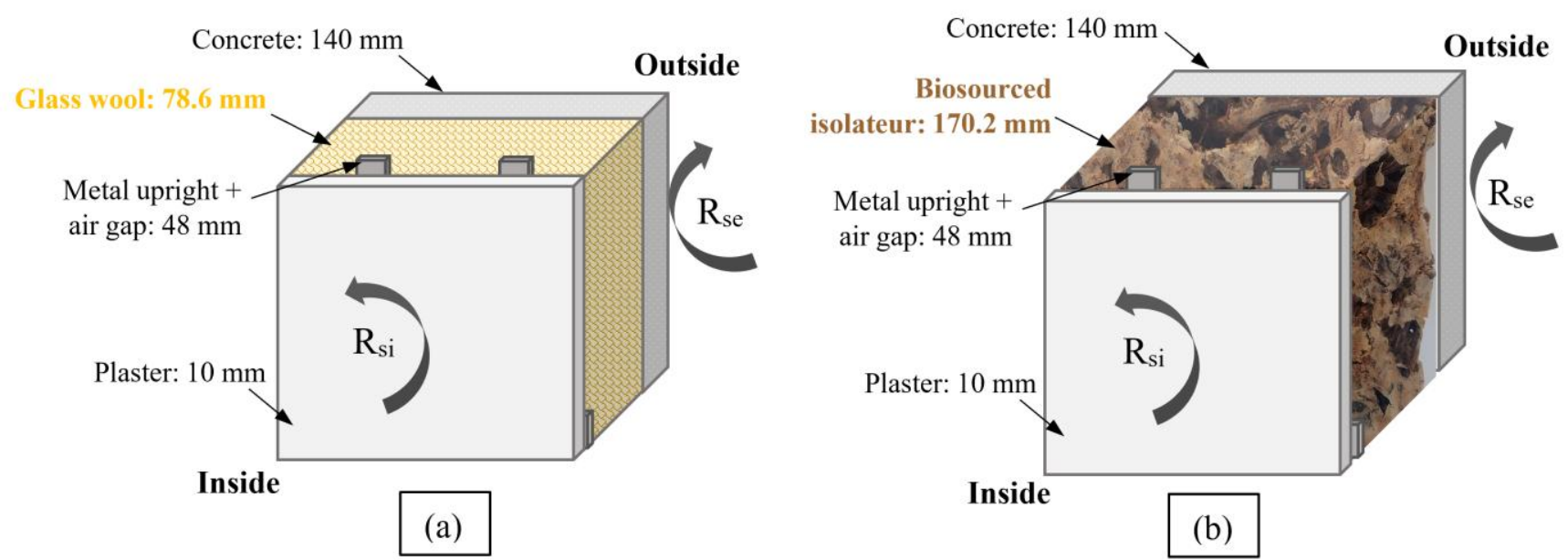

Figure 6: Example of an entire wall (a) with glass wool insulation and (b) with bio-based organic insulation (S/S with $20 \%$ of starch)

Two types of walls with the same types of elements except for the insulation layer were compared. The wall structures are shown in Fig. 6: the first one with a glass wool insulation (Fig. 6a), and the second one with the starch/stalk insulation (Fig. 6b). The A/S composite was chosen because it had the lowest thermal conductivity of the four composites. The goal was to determine the thickness of insulation required in the wall to have the same thermal resistance of $2.9 \mathrm{~m}^{2} \mathrm{~K} / \mathrm{W}$ on the wall in both cases. For this purpose, the values of surface exchange thermal resistance of an external surface $\left(R_{\text {se }}=0.04\right)$ and an internal surface $\left(\mathrm{R}_{\mathrm{si}}=0.13\right)$ were taken as these are standard values used in France. The thermal resistances of concrete, plaster and studs were calculated from the thermal conductivity and thickness. To have the sum of the thermal resistances equal to $2.9 \mathrm{~m}^{2} \mathrm{~K} / \mathrm{W}$, the thermal resistance of the insulation must be $2.4556 \mathrm{~m}^{2} \mathrm{~K} / \mathrm{W}$. Taking the thermal conductivity of glass wool equal to $0.032 \mathrm{~W} /(\mathrm{mK})$, the required thickness is $78.6 \mathrm{~mm}$. For the composite $\mathrm{S} / \mathrm{S}$, with $\lambda=$ $0.0693 \mathrm{~W} /(\mathrm{mK})$, the insulation thickness is $170.2 \mathrm{~mm}$.

\subsection{Mechanical characteristics}

The studied composites were not intended to be used as structural or load-bearing materials. For use as insulating layer, the materials must be able to support their own weight keeping structural integrity. The results for all bending or compression test are very close for all samples, which gives an indication of the composites homogeneity of the compositions.

Fig. 7 shows the averaged curves of the stress versus strain evolution of each composition for the 3-point bending. The $\mathrm{A} / \mathrm{GP}$ and A/CS composites have high modulus of elasticity of 2.52 and $3.56 \mathrm{MPa}$ respectively while A/S and A/P composites have modulus of 0.80 and $1.40 \mathrm{MPa}$. For the rupture strength of the composites, the behaviors are quite different. $\mathrm{A} / \mathrm{P}$ has a clean fracture at $0.3 \mathrm{MPa}$ for a $4 \mathrm{~mm}$ deflection. The rupture seems to be caused by the lack of adhesion between the grape skins. A/GP. For A/CS compositions have rupture strength of 0.43 and $0.61 \mathrm{MPa}$ respectively. For the A/S composite, the behavior is very different: no sharp sample break was obtained; only a fiber compression was observed (Fig. 8a). In comparison, an extruded polystyrene insulation has a bending strength of 0.62 to $1 \mathrm{MPa}$ [44].

The stiffness of composites depends on the stiffness, microstructure, and the aggregates geometry. Differences in the shape of the aggregates have an impact on the modulus of elasticity and fracture of the materials. The presence of stalks in the composites helps to maintain the cohesion and rigidity of the materials in bending. 


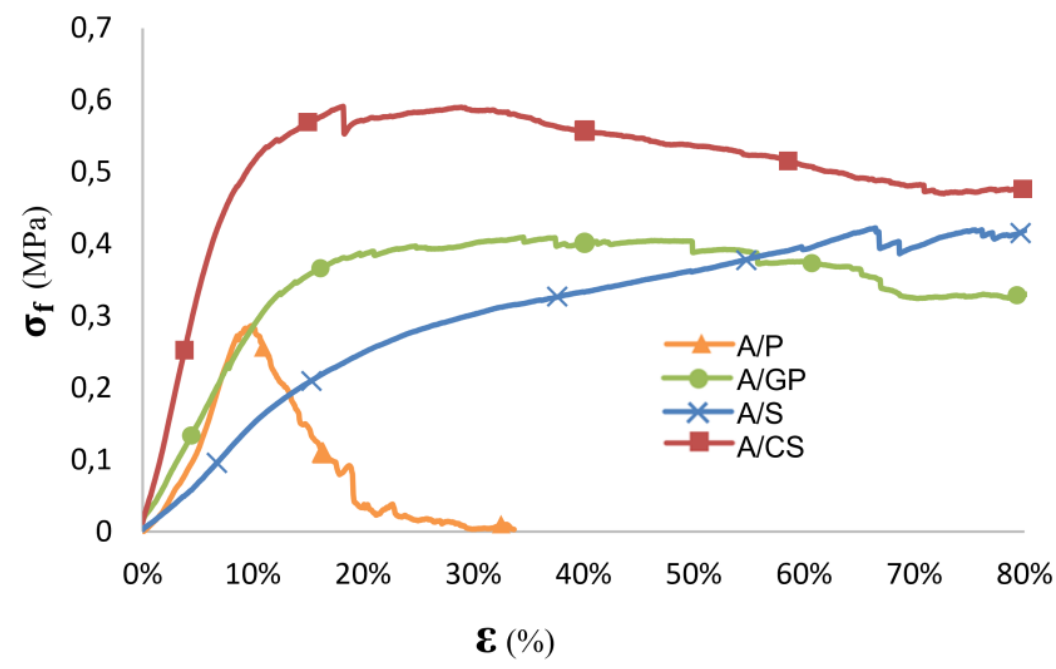

Figure 7: Bending stress-strain curves for different grape composites in bending (with $20 \%$ of starch)
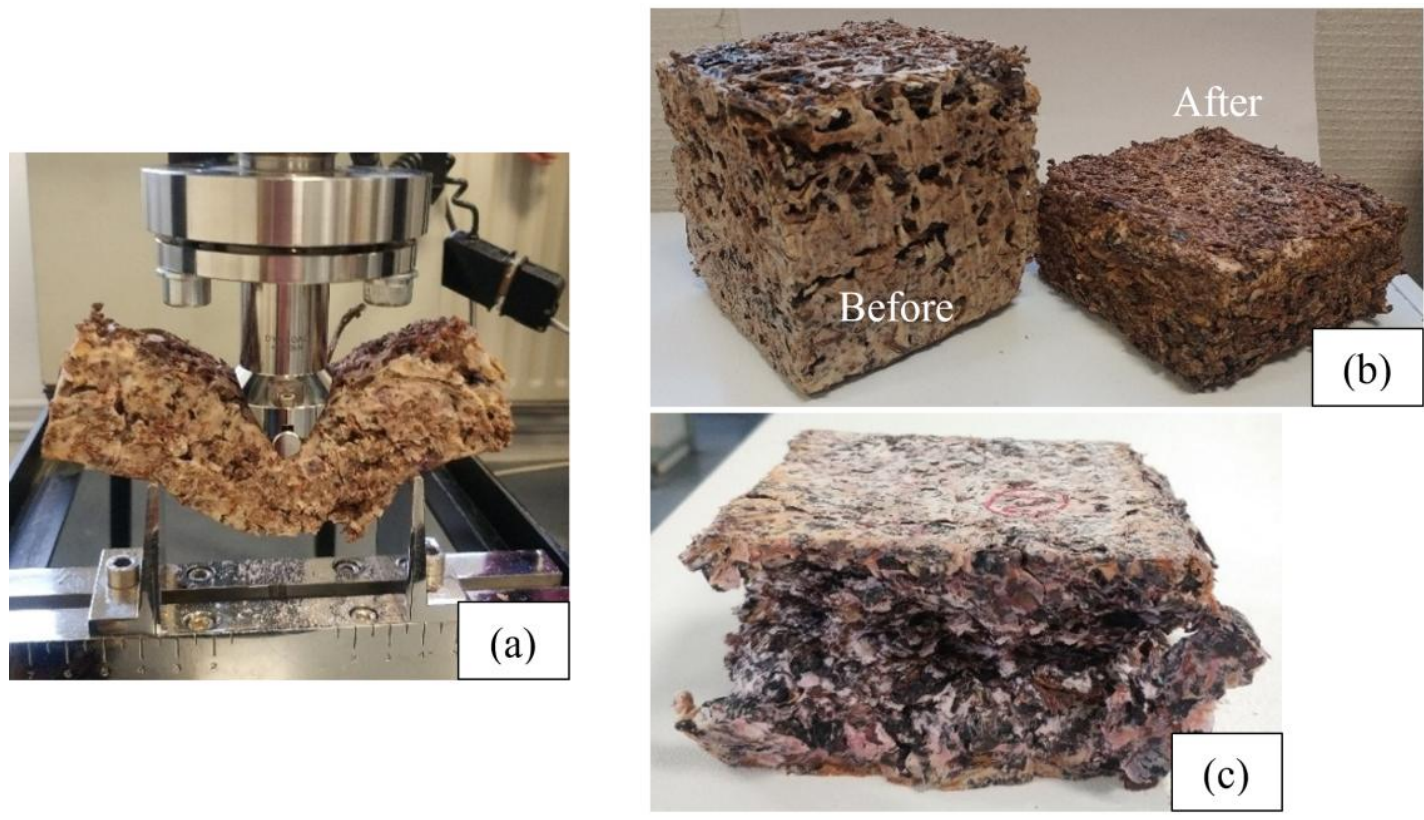

Figure 8: (a) Bending test specimen A/S, (b) bricks A/S before/after compression test, (c) brick A/P after compression test

Composite should exhibit a sufficient compression modulus (typically in the range of 6.5 to 25 MPa [44]) to meet the application requirements as insulation for walls in buildings and constructions where the materials are mainly subjected to compression loads.

Fig. 9 shows the average curves of the stress versus strain evolution of each composition for compression. The curves show two different behaviors: an initial linear behavior and a pseudo-exponential behavior (densification). This behavior is similar to those of highly porous materials such as foams [45]. In the linear zone, there is a collapse of the cells one after the other followed by a densification of the particles which, gives this pseudo-exponential zone (Fig. 8b). The initial linear slope is used to calculate the compressive modulus of the composites while the maximum stress at break is taken as the compressive strength. It can be observed that the stress-strain curves are linear up to about $25 \%$ strain for A/CS and $40 \%$ strain for $\mathrm{A} / \mathrm{P}, \mathrm{A} / \mathrm{GP}$ and $\mathrm{A} / \mathrm{S}$, indicating that the material has elastic behavior in this area.

The trend for A/S, A/CS and A/GP compositions is similar. The modulus of elasticity of the composites are equivalent to 33.3 MPa, 34.2 MPa and 36.1 MPa respectively. The compression tests stopped at 50kN, the limit of the machine. The A/P composite has a lower modulus of elasticity of 11.7 MPa and a stress at break of 3.0 MPa. Specimen failure was caused by the delamination of the skins on the side faces of the specimen see Fig. 8c. In comparison, commercial polystyrene has a compressive strength between 0.27 and $0.69 \mathrm{MPa}$ [44]. 


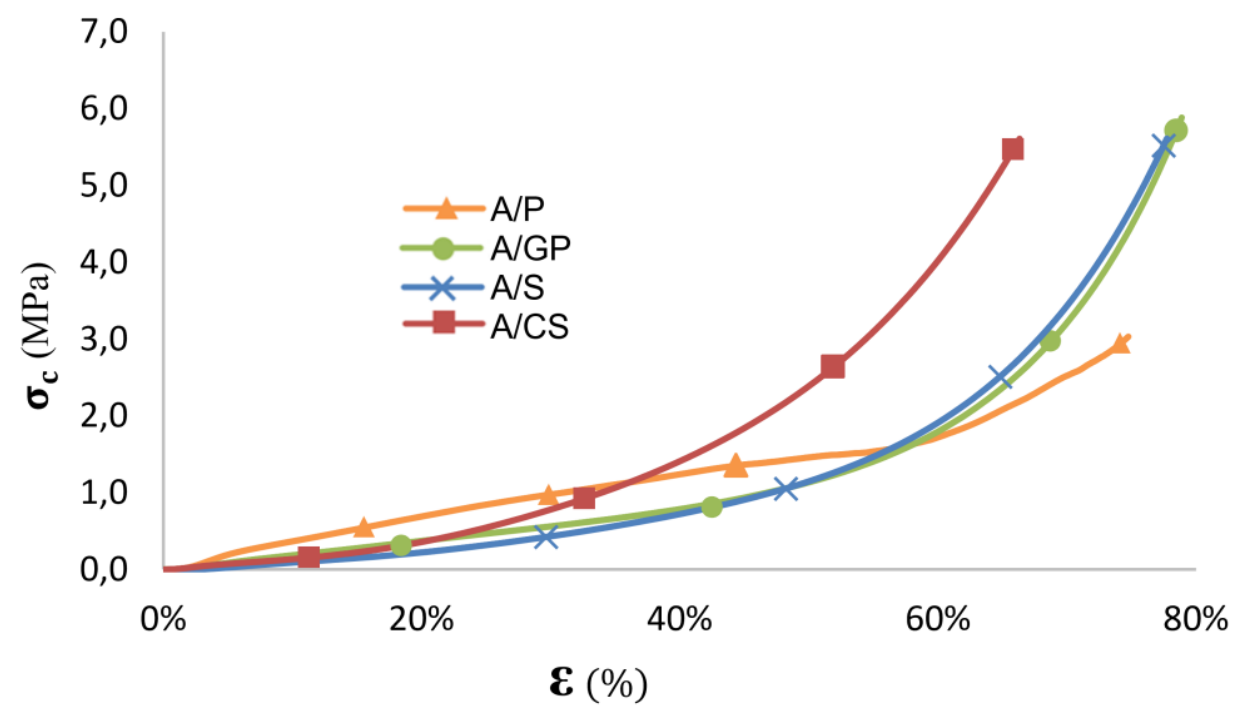

Figure 9: Compressive strain-stress curves for different grape composites in compression (with 20\% of starch)

The rigidity of the material is the combination of aggregate stiffness, the internal microstructure of the specimens (arrangement of the aggregates together) and the adhesion between the elements. When looking at the mechanical properties of polystyrene used in insulation, the bending strength is similar for A/CS composite and slightly lower for the others. Compressive strength is better for all composites compared to polystyrene boards. Composites do not bend are their own weight and withstand high compressive stress. They can be used as non-load-bearing insulation panels.

\subsection{Acoustic characteristics}

Soundwaves reflected on the surface of a room interfere with the incident waves and hinder the intelligibility of speech (echo problem). Porous, lightweight material have this ability to dissipate part of the incident wave energy through an absorption phenomenon, resulting in effective absorption properties over a wide range of frequencies. Acoustic absorption is used to reduce the nuisance of noise emitted in a room. The sound absorption coefficient of our composites were measured by the impedance tube method.

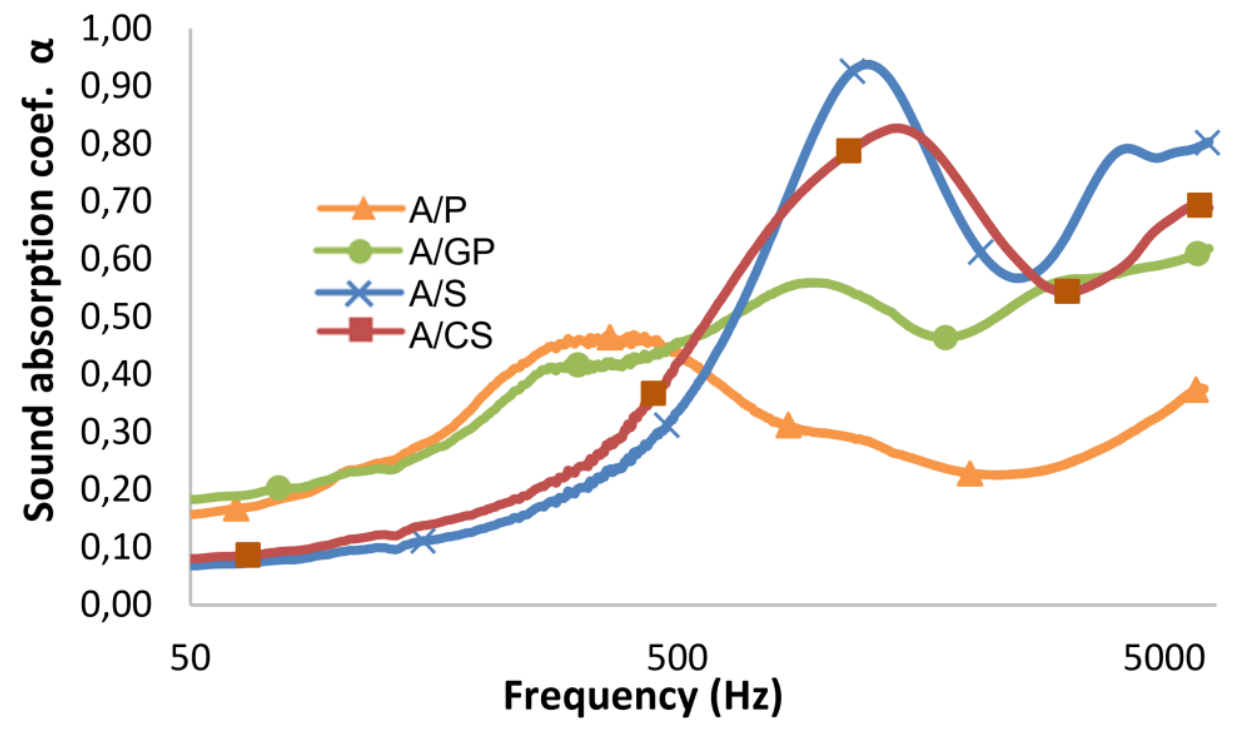

Figure 10: Sound absorption coefficient with frequency sweep for starch/by-products

Fig. 10 shows the variation of sound absorption as a function of sound frequency for the different composites for $20 \mathrm{~mm}$ thick sample. For all samples, the absorption tends towards 0 at low frequencies because the wavelength is then large in front of the characteristic dimensions of the sample. Two distinct behaviors can be observed depending on the samples. For $\mathrm{A} / \mathrm{S}$ and $\mathrm{A} / \mathrm{CS}$, the absorption peaks are located between 1000 and $1400 \mathrm{~Hz}$ and reach values of 0.93 and 0.83 respectively. Then the curves decrease before reaching other peaks at high frequencies. For samples A/P and A/GP, the first peaks appear around $400 \mathrm{~Hz}$ and the overall level of absorption is attenuated. 
It can be seen that the three compounds (A/P, A/GP and A/CS) with closed porosities have acoustic absorption values close to each other since this porosity allows the acoustic waves to penetrate the material before being dissipated. On the other hand, the stalks-based material has very wide-open porosities, which gives it less acoustic characteristics. It should be noted that these data are based on a small sample thickness of $20 \mathrm{~mm}$. Varying the thickness can be considered as a lever for controlling the acoustic properties. Future studies will focus on this aspect.

The materials have a high porosity, the incident wave penetrates the material and is damped along the capillaries by viscous effects. The materials have several characteristic sizes of pores (intra-particle air, intra-binder air or macroscopic air), it can be assumed that the material has several types of porosity. Based on this assumption, it can be explained the experimental observation of several absorption peaks over the frequency range. [46]

Compared to other bio-based materials, the sunflower steam composite (thickness $=15 \mathrm{~mm}$ ) has a maximum absorption coefficient of 0.4 between 1000 and $4000 \mathrm{~Hz}$ [47] and the rice/resin and wood plywood panels (thickness=10mm) also have coefficients of 0.4 for the whole frequency range [48].

The $\alpha_{\mathrm{w}}$ parameter can vary from 0 to 1 in five absorption classes from A to E. Class A is the class with the highest absorption coefficient. Fig. 11 shows the sound absorption coefficient $\left(\alpha_{\mathrm{w}}\right)$ and the practical absorption coefficient $\left(\alpha_{\mathrm{p}}\right)$ of the different mixtures as a function of frequency. The A/GP composite has the highest sound absorption coefficient (0.425) among the four compositions while the A/S composite has the lowest $\alpha_{\mathrm{w}}(0.275)$. It belongs to absorption class D.
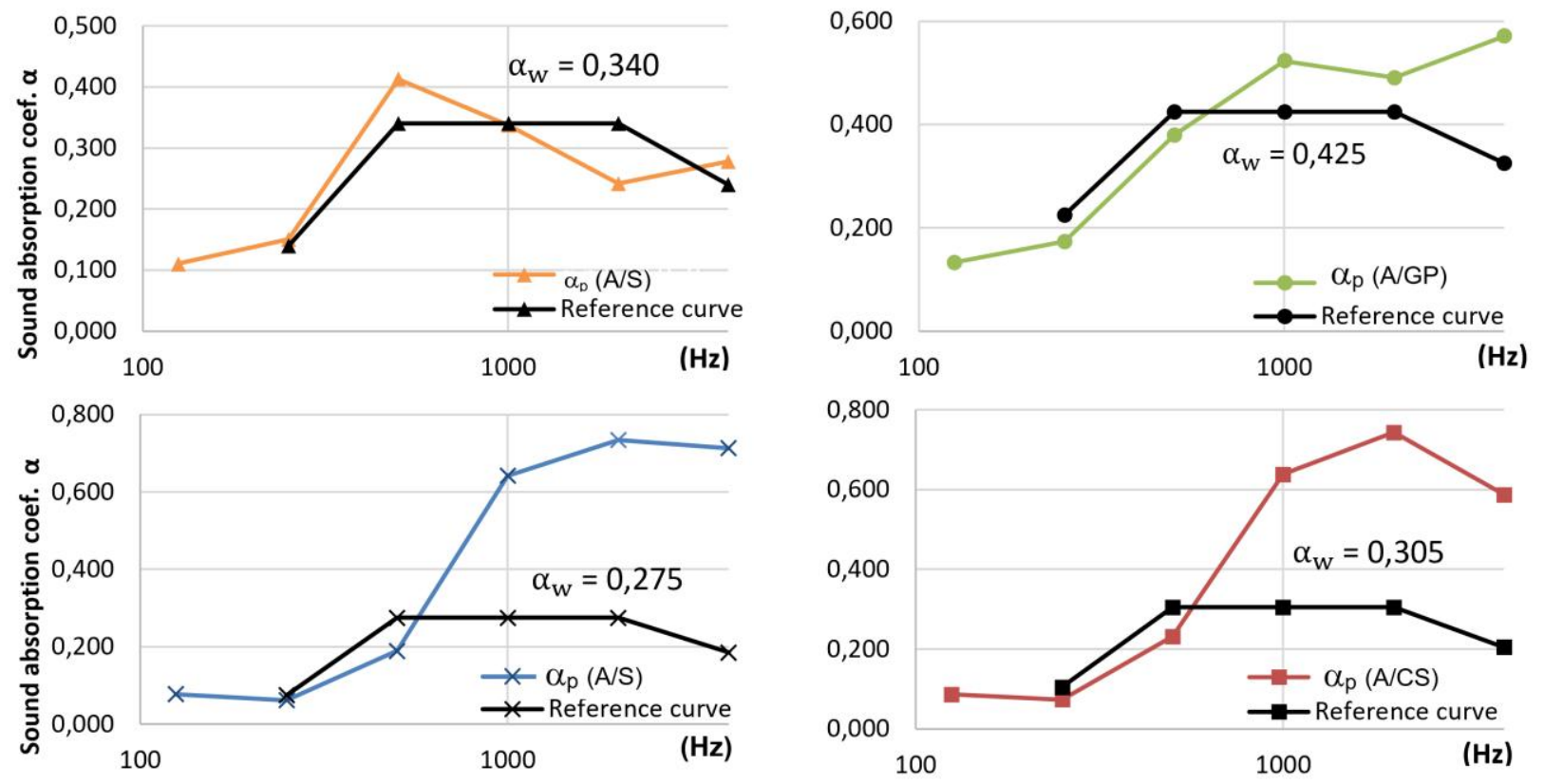

Figure 11: Measured sound absorption coefficient $\left(\alpha_{\mathrm{w}}\right)$ and the practical absorption coefficient $\left(\alpha_{\mathrm{p}}\right)$ of the different mixtures as a function of frequency

The commercial insulation materials, Table 5, are made of glass wool, rock wool, polyurethane foam, polystyrene, etc. These materials have good thermal and acoustic insulation properties but are non-sustainable, non-biodegradable and harmful for the environment. Composites based on grape pomace come from renewable resources and are biodegradable.

Table 5: Comparative table of sound absorption coefficients at central frequencies of different commercially available components used in sound insulation (commercial product data)

\begin{tabular}{|c|c|c|c|c|}
\hline Materials & Ref. & $\begin{array}{c}\text { Thickness } \\
(\mathrm{mm})\end{array}$ & $\boldsymbol{\alpha}_{\mathrm{w}}$ & Class \\
\hline 'ISOVER PAR®' Glass wool (Wall) & [49] & 30 & 0.6 & $\mathrm{C}$ \\
\hline 'ISOVER Alphalene 50®' Rock wool (Wall) & [49] & 30 & 0.6 & $\mathrm{C}$ \\
\hline 'Dox panneau PV' Polyester fibers (Wall, ceiling) & {$[50]$} & 50 & 0.75 & $\mathrm{~B}$ \\
\hline 'Dox Sonex PU 20/3' Polyurethane foam (Wall, ceiling) & {$[51]$} & 35 & 0.35 & $\mathrm{D}$ \\
\hline 'Rockfon Blanka ${ }^{\circledR}$ A15 Bas' (Ceiling tiles) Rock wool & {$[52]$} & 20 & 0.25 & $\mathrm{E}$ \\
\hline $\mathrm{A} / \mathrm{GP}$ & - & 20 & 0.425 & $\mathrm{D}$ \\
\hline
\end{tabular}


By comparing the $\alpha_{\mathrm{w}}$ parameter of our composites with marketed products, A/S and A/GP composites can be used as insulation in the form of ceiling panels or walls for classrooms, public institutions (class E and D) and acoustic insulation in libraries, museums for example. Knowing that the coefficient measured here is for a thickness of $20 \mathrm{~mm}$. To better understand the acoustic property of these composites, measurements with different thicknesses will be carried out.

\subsection{Synthesis}

The Table 6 summarizes all the results obtained in this study: the mechanical properties of compression and bending (Young's modulus $(E)$, stress $(\sigma)$ and strain $(\varepsilon)$ ), density $(\rho)$, thermal conductivity $(\lambda)$ and measured sound absorption coefficient $(\alpha w)$.

Table 6: Synthesis of the results obtained for the different compounds with $20 \%$ of starch.

\begin{tabular}{|c|c|c|c|c|c|c|c|c|c|}
\hline Composites & $\begin{array}{c}\mathbf{E}_{\mathbf{C}} \\
(\mathrm{MPa})\end{array}$ & $\begin{array}{c}\boldsymbol{\sigma}_{\mathrm{C}} \\
(\mathrm{MPa})\end{array}$ & $\begin{array}{c}\boldsymbol{\varepsilon}_{\mathrm{C}} \\
(\%)\end{array}$ & $\begin{array}{c}\mathbf{E}_{\mathrm{f}} \\
(\mathrm{MPa})\end{array}$ & $\begin{array}{c}\sigma_{\mathrm{f}} \\
(\mathrm{MPa})\end{array}$ & $\begin{array}{c}\boldsymbol{\varepsilon}_{\mathrm{f}} \\
(\%)\end{array}$ & $\begin{array}{c}\boldsymbol{\rho}_{\text {real }} \\
\left(\mathrm{kg} / \mathrm{m}^{3}\right)\end{array}$ & $\begin{array}{c}\lambda \\
(\mathrm{W} /(\mathrm{mK}))\end{array}$ & $\boldsymbol{\alpha}_{w}$ \\
\hline $\mathbf{A} / \mathbf{P}$ & $11.7 \pm 1.9$ & $3,0 \pm 0.1$ & $71.6 \pm 4.0$ & $2.5 \pm 0,6$ & $0,30 \pm 0,07$ & $24,9 \pm 7,6$ & $433 \pm 78$ & $\begin{array}{l}0.0793 \\
\pm 0.0033\end{array}$ & 0.340 \\
\hline A/GP & 36 & 5. & 7 & 3 & 3 & & 30 & $\begin{array}{l}0.0759 \\
\pm 0.0067\end{array}$ & 0.425 \\
\hline $\mathbf{A} / \mathbf{S}$ & 33.3 & $5.6 \pm 0.1$ & $79.4 \pm 5.9$ & $0.0 \pm$ & $0,45 \pm 0,06$ & $86,6 \pm 0,4$ & 227 & $\begin{array}{l}0.0693 \\
\pm 0.0039\end{array}$ & 0.275 \\
\hline $\mathrm{A} / \mathrm{CS}$ & $34.2 \pm 4.5$ & $5.6 \pm 0.1$ & $66.7 \pm 1.2$ & $3.6 \pm 0,1$ & $0,61 \pm 0,06$ & $88,1 \pm 0,7$ & $345 \pm 35$ & $\begin{array}{l}0.0776 \\
\pm 0.0015\end{array}$ & 0.305 \\
\hline
\end{tabular}

The insulation performance criteria for material are defined by the hardness of the material (the mechanical properties in compression) the flexibility of the insulation (the behavior to differential movements), the alterability of the products (the water behavior), the strength of the material (the mechanical properties useful for cohesion and bending), and the watertightness of the product (the permeability to water or water vapor).

Compression results confirm moderate performance with a compressive strength between 3.0 and 5.9 MPa and a young's modulus ranging from 11.7 to $36 \mathrm{MPa}$ for samples with an average density of around $300 \mathrm{~kg} / \mathrm{m}^{3}$. These results confirm that the bio-sourced material studied cannot be used as a load bearing in building construction materials. On the mechanical, thermal, and acoustic points of view, by-products/starch composites can be considered as insulation materials; composite stalks (A/S) has the highest thermal insulating properties, and composite A/GP displayed the best acoustic insulating properties.

In this study, mechanical, thermal, and acoustic properties were measured. The hydric properties of the materials will be reported in a forthcoming study.

\section{Conclusion}

The objective of this work was to develop a new method of manufacturing 100\% natural eco-insulating materials based on grape pomace bound with potato starch. Mechanical, thermal, and acoustic properties of the composites were studied for potential use in building insulation. Shape, density, and nature of the aggregates (stalks, grape pomace, skins, and crushed stalks) are factors that influence the porosity of the composites.

The four composites had similar values of thermal conductivity. The stalks composite has a thermal conductivity of 0.069 $\mathrm{W} /(\mathrm{m} . \mathrm{K})$ while the skin composite has a thermal conductivity equal to $0.079 \mathrm{~W} /(\mathrm{mK})$ for the same conditions, suitable for public buildings insulation use.

The grape pomace-based composites have foams-like compression behaviors, young's modulus ranging from $11.7 \mathrm{MPa}$ to 36.1 MPa for skins and grape pomace respectively. Compression showed that there was no rupture but first a collapse of the voids followed by mass effect. The composites have a bending strength between 0.3 and $0.6 \mathrm{MPa}$. The starch/grape pomace (A/GP) composite has the best behavior in compression and the starch/crushed stalks (A/CS) composite is the best in bending.

The starch/grape pomace (A/GP) has a sound absorption coefficient of 0.42 for a thickness of 20 mm. These results shows that, our composite have acoustic properties that belong to class $\mathrm{D}$ or $\mathrm{E}$ and can be used in insulation in public buildings. 
Further research will focus on the proportion of starch in the composites to evaluate its influence on thermal, mechanical and acoustic properties. In addition, their hygrothermal behavior must be studied in order to test their ability to insulate buildings, and to act as a water buffer.

\section{Conflict of Interest}

None

\section{Acknowledgment}

This research was funded by the Communauté d'Agglomération de Châlons-en-Champagne (France) through a PhD grant, the EXPERI platform and the Pôle de Recherche Châlonnais for its material assistance.

\section{References}

[1] A. Invidiata, M. Lavagna, E. Ghisi, Selecting design strategies using multi-criteria decision making to improve the sustainability of buildings, Build. Environ. 139 (2018) 58-68, https://doi.org/10.1016/j.buildenv.2018.04.041

[2] European Parliament and Council, Directive 2018/844 of 30 May 2018 amending Directive 2010/31/EU on the energy performance of buildings and Directive 2012/27/EU on energy efficiency. PE/4/2018/REV/1, Off J Eur, L, (2018) 156

[3] M.V. Madurwar, R.V. Ralegaonkar, S.A. Mandavgane, Application of agro-waste for sustainable construction materials: A review, Constr. Build. Mater. 38 (2013) 872-878, https://doi.org/10.1016/j.conbuildmat.2012.09.011

[4] N. Hajj, B. Maboumba-Mamboundou, R. Dhailly, Z. Aboura, M. Benzegggh, M. Queneudec, Development of thermal insulating and sound absorbing agro-sourced materials from auto linked flax-tows, Ind. Crops Prod. 34 (2011) 921-928, https://doi.org/10.1016/j.indcrop.2011.02.012

[5] G. Balciunas, J. Žvironaite, S. Vejjelis, A. Jagniatinskis, S. Gaidučis, Ecological, thermal and acoustical insulating composite from hemp shives and sapropel binder, Ind. Crops Prod. 91 (2016) 286-294, https://doi.org/10.1016/j.indcrop.2016.06.034

[6] P. Lertsutthiwong, S. Khunthon, K. Siralertmukul, K. Noomun, S. Chandrkrachang, New insulating particleboards prepared from mixture of solid wastes from tissue paper manufacturing and corn peel, Bioresour. Technol. 99 (2008) 4841-4845, https://doi.org/10.1016/j.biortech.2007.09.051

[7] N. Mati-Baouche, H. De Baynast, A. Lebert, S. Sun, C. Lopez-Mingo, P. Leclaire, P. Michaud, Mechanical, thermal and acoustical characterizations of an insulating bio-based composite made from sunflower stalks particles and chitosan, Ind. Crops Prod. 58 (2014) 244-250, https://doi.org/10.1016/j.indcrop.2014.04.022

[8] P.A. Chabriac, E. Gourdon, P. Glé, A. Fabbri, H. Lenormand, Agricultural by-products for building insulation: Acoustical characterization and modeling to predict micro-structural parameters, Constr. Build. Mater. 112 (2016) 158167, https://doi.org/10.1016/j.conbuildmat.2016.02.162

[9] X. Zhou, F. Zheng, H. Li, C. Lu, An environment-friendly thermal insulation material from cotton stalk fibers, Energy and Build. 42 (2010) 1070-1074, https://doi.org/10.1016/j.enbuild.2010.01.020

[10] G. Quintana, J. Velásquez, S. Betancourt, P. Gañán, Binderless fiberboard from steam exploded banana bunch, Ind. Crops Prod. 29 (2009) 60-66, https://doi.org/10.1016/j.indcrop.2008.04.007

[11] K. Wei, C. Lv, M. Chen, X. Zhou, Z. Dai, D. Shen, Development and performance evaluation of a new thermal insulation material from rice straw using high frequency hot-pressing, Energy and Build. 87 (2015) 116-122, https://doi.org/10.1016/j.enbuild.2014.11.026

[12] R.S. Al-Juruf, F.A. Ahmed, I.A. Alam, H.H. Abdel-Rahman, Development of Heat Insulating Materials Using Date Palm Leaves, Journal of Thermal Insulation 11 (1988) 158-164, https://doi.org/10.1177\%2F109719638801100304

[13] S. Tangjuank, Thermal insulation and physical properties of particleboards from pineapple leaves, Int. J. Phys. Sci 6 (2011) 4528-4532, https://doi.org/10.5897/IJPS11.1057

[14] F. Asdrubali, F. D’Alessandro, S. Schiavoni, N. Mencarelli, Sound absorption properties of Reed, Report, ICSV22, Florence (Italy) 12-16 July 2015.

[15] K. Manohar, Experimental Investigation of Building Thermal Insulation from Agricultural By-products, Br J Appl Sci Technol 2 (2012) 227-239, https://doi.org/10.9734/BJAST/2012/1528 
[16] A.C. Gowman, M.C. Picard, L.T. Lim, M Misra, A.K. Mohanty, Fruit Waste Valorization for Biodegradable Biocomposite Applications : A Review, BioRes. 14 (2019) 10047-10092, https://doi.org/10.15376/biores.14.4.Gowman

[17] IFV, Marcs de raisins, lies de vin et bourbes : Quelle gestion des sous-produits vinicoles, Rapport, 2013, Itinéraires $\mathrm{n}^{\circ} 25$

[18] N. Zhan, A. Hoadley, J. Patel, S. Lim, C. Li, Sustainable options for the utilization of solid residues from wine production, Waste Manage. 60 (2017) 173-183, https://doi.org/10.1016/j.wasman.2017.01.006

[19] J. El Achkar, Méthanisation de marc de raisin. Caractérisation et optimisation du procédé et des prétraitements, Thesis Université de Bretagne Sud, 2017.

[20] R. Devesa-Rey, X. Vecino, J.L. Varela-Alende, M.T. Barral, J.M. Cruz, A.B. Moldes, Valorization of winery waste vs. the costs of not recycling, Waste Manage. 31 (2011) 2327-2335, https://doi.org/10.1016/j.wasman.2011.06.001

[21] C. Nurgel, A. Canbas, Production of Tartaric Acid From Pomace of Some Anatolian Grape Cultivars, Am. J. Enol. Vitic 49 (1998) 95-99.

[22] Y. Hang, E.E. Woodams, Grape pomace: A novel substrate for microbial production of citric acid, Biotechnol. Lett 7 (1985) 253-254, https://doi.org/10.1007/BF01042372

[23] F. Saura-Calixto, Antioxidant Dietary Fiber Product: A New Concept and a Potential Food Ingredient, J. Agric. Food Chem. 46 (1998) 4303-4306, https://doi.org/10.1021/jf9803841

[24] J.-C. Pierron, L'huile de pépins de raisin en France et dans le monde, OCL 24 (2017) 5, https://doi.org/10.1051/ocl/2017034

[25] J.M. Souquet, B. Labarbe, C. Le Guernevé, V. Cheynier, M. Moutounet, Phenolic composition of grape stems, J. Agric. Food Chem. 48 (2000) 1076-1080, https://doi.org/10.1021/jf991171u

[26] E. Kalli, I. Lappa, P. Bouchagier, P. Tarantilis, E. Skotti, Novel application and industrial exploitation of winery byproducts, Boiresour. Bioprocess. 5 (2018) 46, https://doi.org/10.1186/s40643-018-0232-6

[27] F. Gambier, Valorisation des marcs de raisins épuisés : vers un procédé d'extraction de tannins condensés à grande échelle pour la production d'adhésifs pour panneaux de particules, Thesis Université de Lorraine, 2014

[28] A. Gowman, T. Wang, A. Rodriguez-Uribe, A.K. Mohanty, M. Misra, Bio-poly (butylene succinate) and Its Composites with Grape Pomace: Mechanical Performance and Thermal Properties, ACS Omega 3 (2018) 15205-15216, https://doi.org/10.1021/acsomega.8b01675

[29] A. Gowman, Sustainable Green Composites from Grape Pomace and Biodegradable Plastics, Thesis University of Guelph, 2019

[30] J.B. Engel, A. Ambrosi, I.C. Tessaro, Development of a Cassava Strach-Based Foam Incorporated with Grape Stalks Using an Experimental Design, J. Polym. Environ. 27 (2019) 2853-2866, https://doi.org/10.1007/s10924-019-01566-0

[31] A. Bourdot, T. Moussa, A. Gacoin, C. Maalouf, P. Vazquez, C. Thomachot-Schneider, C. Bliard, A. Merabtine, M. Lachi, O. Douzane, H. Karaky, G. Polidori, Characterization of a hemp-based agro-material: Influence of starch ratio and hemp shive size on physical, mechanical, and hygrothermal properties, Energy and Build. 153 (2017) 501-512, https://doi.org/10.1016/j.enbuild.2017.08.022

[32] A.T. Le, A. Gacoin, A. Li, N. El Walkil, Comportement mécanique et acoustique d'un biocomposite 100\% végétal à base de chènevotte et d'amidon, Rencontres Universitaires de Génie Civil, May 2015, Bayonne, France.

[33] R. Belakroum, A. Gherfi, K. Bouchema, A. Gharbi, Y. Kerboua, M. Kadja, C. Maalouf, T.H. Mai, N. El Wakil, M. Lachi, Hygric buffer and acoustic absorption of new building insulation materials based on date palm fibers, J. Build. Eng. 12 (2017) 132-139, https://doi.org/10.1016/j.jobe.2017.05.011

[34] L. Kaur, N. Singh, N. S. Sodhi, Some properties of potatoes and their starches II. Morphological, thermal and rheological properties of starches, Food Chem. 79 (2002) 183-192, https://doi.org/10.1016/S0308-8146(02)00130-9

[35] Y. Jiang, J. Simonsen, Y. Zhao, Compression-molded biocomposite boards from red and white wine grape pomaces, J. Appl Polym. Sci. 119 (2011) 2834-2846, https://doi.org/10.1002/app.32961

[36] L. Ping, N. Brosse, P. Sannigrahi, A. Ragauskas, Evaluation of grape stalks as a bioresource, Ind. Crops Prod. 33 (2011) 200-204, https://doi.org/10.1016/j.indcrop.2010.10.009 
[37] J.A.S. Mendes, A.M.R.B. Xavier, D.V. Evtuguin, L.P.C. Lopes, Integrated utilization of grape skins from white grape pomaces, Ind. Crops Prod. 49 (2013) 286-291, https://doi.org/10.1016/j.indcrop.2013.05.003

[38] H. Karaky, Elaboration et caractérisation d'un agromatériau pulpe de betterave sucrière et amidon pour une application dans le bâtiment, Thesis Université de Reims Champagne Ardenne, 2018.

[39] B. S Umurigirwa-Vasseur B. S, Elaboration et caractérisation d'un agromatériau chanvre-amidon pour le bâtiment , Thèse, Université de Reims Champagne-Ardenne, 2014.

[40] H. Karaky, C. Maalouf, C. Bliard, A. Gacoin, M. Lachi, N. El Wakil, G. Polidori, Characterisation of beet-pulp fiber reinforced potato biopolymer comosites for building applications, Constr. Build. Mater. 203 (2019) 711-721, https://doi.org/10.1016/j.conbuildmat.2019.01.127

[41] H. Lenormand, A. Mahieu, N. Leblanc, A. Vivet, Nouvelles agroressources pour panneaux de particules $100 \%$ biosourcés, Conférence Matériaux 2014 - Colloque Ecomatériau, Nov 2014, Montpellier, France.

[42] Sénova, RT2012 et RT existant - Réglementation thermique et efficacité énergétique $3^{\mathrm{e}}$ édition, Editions Eyrolles Environnement (2015) 65-68.

[43] Arrêté du 3 mai 2007 relatif aux caractéristiques thermiques et à la performance énergétique des bâtiments existants, https://www.legifrance.gouv.fr/loda/id/JORFTEXT000000822199/

[44] Owens Corning®, Product https://dcpd6wotaa0mb.cloudfront.net/mdms/dms/Residential\%20Insulation/501125CA/501125-Foamular-NGX-400-6001000-Data-Sheet-FR.pdf?v=1608629113000 , 2021

[45] M.C. Saha, Md. E. Kabir, S. Jeelani, Enhancement in thermal and mechanical properties of polyurethane foam infused with nanoparticles, Mater. Sci. Eng A 479 (2008) 213-222, https://doi.org/10.1016/j.msea.2007.06.060

[46] V. Cerezo, Propriétés mécaniques, thermiques et acoustiques d'un matériau à base de particules végétales: approche expérimentale et modélisation théorique, Thèse, l'Institut National des Sciences Appliquées de Lyon, 2005.

[47] H. Lenormand, P. Glé, N. Leblanc, Investigation of the Acoustical and Thermal Properties of Sunflower Particleboards, Acta Acust United Acust 103 (2017) 149-157, https://doi.org/10.3813/AAA.919040

[48] H.-S. Yang, D.-J. Kim, H.-J. Kim, Rice straw-wood particule composite for sound absorbing wooden construction materials, Bioresour. Technol. 86 (2003) 117-121, https://doi.org/10.1016/s0960-8524(02)00163-3

[49] ISOVER Documentation on their acoustic products.

https://www.isover.fr/sites/isover.fr/files/assets/documents/catalogue solutions $78 \quad 82$ absorption_acoustique.pdf, 2021

[50] DOX acoustics website, Product Description. https://www.doxacoustics.be/fr/produits/solutionsacoustiques/panneaux-muraux-et-de-plafond/panneau-pv , 2021

[51] DOX acoustics website, Product Description. https://www.doxacoustics.be/fr/produits/solutionsacoustiques/panneaux-structures/sonex , 2021

[52] Rockfon website, Product Description. https://www.rockfon.fr/produits/rockfon-blankabas/?selectedCat=fiches $\% 20$ techniques $\% 20 \% 20$ plafonds $\% 20$ et $\% 20$ panneaux $\% 20$ muraux\#Performances , 2021 